MALLOMO: Journal of Community Service

https://jurnal.umsrappang.ac.id/mallomo/index

Vol 1, No, 1, Desember 2020, pp 22-29

\title{
Analisa Kelayakan Usaha Pembuatan Selai Apel di UMS Rappang Store
}

\author{
Nurul Qisti ${ }^{1}$, Andi Nurwidah ${ }^{2}$, Astrini Padapi ${ }^{3}$, Iranita Haryono ${ }^{4}$ \\ 1,2 Teknologi Hasi Pertanian, Universitas Muhammadiyah Sidenreng Rappang \\ Email: nuqyss@gmail.com \\ 3,4 Agribisnis, Universitas Muhammadiyah Sidenreng Rappang
}

\section{Kata Kunci:}

apel, selai, analisis,

kelayakan, usaha

Kata Kunci:

Apples, jam, analysis, feasibility, effort
Abstract. Apples contain many nutritional components, both minerals and vitamins. One of the products sold at UMS Rappang Store is an apple. Apple is a fruit that is easily damaged so as to increase its value by processing the product. Processing carried out is making jam. In addition, a business feasibility analysis was conducted to determine whether or not it was feasible to make apple jam for an alternative business. The results obtained in this analysis are that it is feasible to make apple jam.

Abstrak. Buah apel mengandung banyak komponene gizi, baik mineral maupun vitamin. Salah satu produk yang dijual di UMS Rappang Store yakni buah apel. Buah apel merupakan buah yang mudah rusak sehingga untuk menambah nilainya dengan melakukan pengolahan produk. Pengolahan yang dilakukan yakni pembuatan selai. Selain itu, dilakukan analisa kelayakan usaha untuk mengetahui layak atau tidaknya dilakukan pembuatan selai apel untuk alernatif usaha. Hasil yang didapatkan dalam analisis ini adalah usaha pembuatan selai apel layak untuk dilakukan.

Coresponden author:

Email: nuqyss@gmail.com

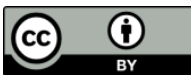

artikel dengan akses terbuka di bawah lisensi CC BY -4.0 


\section{3 | MALLOMO: Journal of Community Service}

\section{Pendahuluan}

\section{A. Latar Belakang}

Buah-buahan mengandung banyak komponen gizi yang baik untuk tubuh. Salah satu buah yang mengandung banyak vitamin adalah buah apel. Buah apel banyak mengandung mineral yang berguna bagi kesehatan manusia. Kandungan protein dan lemak relatif sedikit. Komponen terbesar buah apel adalah air. Menurut Susanto dan Saneto (1994), dari segi komposisi kimianya, buah apel mempunyai nilai gizi yang cukup tinggi. Buah apel juga mengandung karoten, karoten memiliki aktivitas sebagai vitamin A dan juga antioksidan yang berguna untuk menangkal serangan radikal bebas penyebab berbagai penyakit degeneratif (Anonymous dalam Nanda, 2016). Apel mengandung banyak vitamin $C$ dan $B$, selain itu apel kerap menjadi pilihan para pelaku diet sebagai makanan substitusi karena kandungan gizinya. Buah apel yang matang ditandai dengan

Salah satu usaha bisnis dari Universitas Muhammadiyah Sidenreng Rappang yakni UMS Rappang Store. UMS Rappang menyediakan hasil-hasil pertanian dan menjadi pusat oleh-oleh khas Sidrap. Salah satu produk yang dijual di UMS Rappang Store yakni buah apel. Namun, kendala dalam penjualan buah apel yakni mudahnya rusak. Beberapa apel yang tidak laku dan mulai rusak diolah kembali menjadi selai sehingga lebih awet dan menambah nilainya. Pembuatan selai tersebut menjadi alternatif untuk keberlanjutan usaha ini. Sehingga, dilakukan analisis usaha untuk mengetahui apakah usaha pembuatan selai ini layak untuk dilakukan. Analisa usaha yang dilakukan yakni menggunakan Analisis Kelayakan Usaha. Pengabdian ini dilakukan karena belum pernah diterapkan di UMS Rappang Store. Hal ini merupakan langkah awal untuk keberlanjutan bisnis Universitas Muhammadiyah Sidenreng Rappang ini.

\section{B. Urgensi dan Rasionalisasi Kegiatan}

Urgensi dari kegiatan ini adalah membantu memecahkan masalah dari UMS Rappang Store mengenai penjualan buah apel yang tidak laku dan mulai rusak. Kegiatan ini dilakukan dengan mengolah langsung produk buah apel dari UMS Rappang Store yang tidak laku dan mulai rusak.

\section{Tinjauan Pustaka}

Selai atau jam adalah makanan yang kental atau semi padat terbuat dari buah-buahan dengan penambahan gula atau dektrosa sehingga menghasilkan makanan awet dengan kandungan total padatan terlarut minimal $65 \%$. Beberapa faktor yang perlu diperhatikan dalam pembuatan selai antara lain pengaruh panas dan konsentrasi gula pada proses pemasakan serta keseimbangan proporsi gula, pektin dan asam. Selai dapat dibuat dari cacahan, sisa saringan/gilingan buah yang dimasak dengan gula sampai campuran lekat dan tetesan dari sendok pada spoon test menyerupai jelly.

Pemanfaatan buah menjadi produk selai mendapatkan keuntungan yang cukup besar. Selai yang dihasilkan juga dapat disimpan dalam kurun waktu yang cukup lama. Kriteria buah yang digunakan dalam pembuatan selai adalah buah yang telah matang dan tidak memiliki tanda-tanda busuk. Buah yang masih muda tidak dapat digunakan untuk pembuatan selai karena masih banyak mengandung pati dan kandungan pektinnya rendah.Salah satu pemanfaatan buah untuk diolahmenjadi selai adalah buah apel. 
Studi kelayakan bisnissangat diperlukan oleh banyak kalangan, khususnya terutama bagi para investor yang selaku pemrakarsa, bank selaku pemberi kredit, dan pemerintah yang memberikan fasilitas tata peraturan hukum dan perundang-undangan, yang tentunya kepentingan semuanya itu berbeda satu sama lainya. Investor berkepentingan dalam rangka untuk mengetahui tingkat keuntungan dari investasi, bank berkepentingan untuk mengetahui tingkat keamanan kredit yang diberikan dan kelancaran pengembaliannya, pemerintah lebih menitik-beratkan manfaat dari investasi tersebut secara makro baik bagi perekonomian, pemerataan kesempatan kerja, dll (Sulastri, 2016).

\section{Solusi Masalah}

Solusi masalah dari penjualan produk buah apel di UMS Rappang Store yakni pembuatan selai apel untuk menambah keuntungan dan menambah nilai produk. Selain itu, dilakukan perhitungan atau analisa kelayakan usahanya untuk mengetahui kelayakan produk selai layak atau tidaknya.

\section{Metode}

Pembuatan Selai Apel dilaksanakan bulan Mei di Laboratorium Dasar Fakultas Sains dan Teknologi, Universitas Muhammadiyah Sidenreng Rappang. Bahan yang digunakan yaitu apel afkir dan gula pasir. Alat yang digunakan yaitu pisau, telenan, baskom, blender, kompor, wajan, sudek, timbangan, botol selai, dan sendok. Pembuatan selai apel diawali dengan pencucian dengan menggunakan air bersih hingga bersih, pengupasan buah apel dan pemotongan. Tahap selanjutnya yaitu pemblenderan buah apel dengan waktu pemblenderan \pm 5 menit. Bubur buah apel, dilakukan penimbangan sesuai dengan formula yang sudah ditentukan. Tahap selanjutnya yaitu pemasukan bubur buah apel kedalam wajan dengan penambahan gula pasir sesuai dengan formula yang sudah ditentukan. Setelah selai apel dingin kemudian selai apel dimasukkan ke dalam botol selai dan siap untuk pengemasan.

\section{Hasil Dan Pembahasan}

Analisa Kelayakan usaha dilakukan untuk mengetahui kapasitas produksi, penjualan, keuntungan maupun kerugian dari produksi pembuatan selai apel. Untuk mengetahui rincian dari perhitungan analisis baiya usaha meliputi :

Perhitungan:

$$
\begin{aligned}
& 1 \text { bulan } \quad=25 \text { hari kerja } \\
& \begin{array}{ll}
1 \text { hari } \quad=1 \text { kali produksi menghasilkan } 100 \text { botol selai } \\
\text { Kapasitas produksi } / \text { bulan } & =100 \text { botol selai } \times 25 \text { hari } \\
& =2500 \text { botol selai }
\end{array}
\end{aligned}
$$

Setiap 1 botol selai memiliki netto 250 gram 
1. Perhitungan Total Biaya tetap (Total Fix Cost)

Tabel 1. Rincian total biaya tetap

\begin{tabular}{|c|c|c|}
\hline No. & Uraian & Biaya/bulan (Rp) \\
\hline 1 & Sewa Bangunan & 2.000 .000 \\
\hline 2 & Biaya Penyusutan & 137.785 \\
\hline 3 & Promosi & 500.000 \\
\hline 4 & Manajer & 1.000 .000 \\
\hline 5 & Amortasi & 1.500 .000 \\
\hline 6 & Dana sosial & 50.000 \\
\hline 7 & Pajak & 1.000 .000 \\
\hline \multicolumn{2}{|r|}{ Total } & 6.187 .785 \\
\hline
\end{tabular}

Sumber: Data Primer, 2020.

2. Perhitungan Total Biaya variabel (Total Variabel Cost)

Tabel 2. Rincian biaya variabel

\begin{tabular}{rlrr}
\hline No. & \multicolumn{1}{c}{ Uraian } & Harga/Hari & \multicolumn{1}{c}{ Harga/Bulan } \\
\hline 1 & Apel & 2.800 .000 & 70.000 .000 \\
2 & Gula Pasir & 120.000 & 3.000 .000 \\
3 & Isi ulang gas kompor & 14.000 & 350.000 \\
4 & Listrik & 8.200 & 205.000 \\
5 & Kemasan + Label & 300.000 & 7.500 .000 \\
6 & Tenaga Kerja 2 orang & 200.000 & 5.000 .000 \\
7 & Biaya Perawatan dan perbaikan alat & 2.495 & 62.375 \\
\hline \multicolumn{2}{c}{ Total } & $\mathbf{2 . 9 4 2 . 2 0 0}$ & $\mathbf{8 6 . 1 1 7 . 3 7 5}$ \\
\hline
\end{tabular}

Sumber: Data Primer, 2020.

3. Biaya produksi

Biaya produksi $=$ Biaya Tetap + Biaya variabel

4. Harga Pokok Produksi (HPP)

Harga Pokok Penjualan $=\frac{\text { Total biaya Produksi per bulan }}{\text { Jumlah produksi per bulan }}$

5. Perhitungan Rugi/ Laba

Laba kotor $=$ Hasil Penjualan per bulan - Total prodksi per bulan

$=$ Rp.97.500.000 $-\mathrm{Rp} 92.305 .160$

$=$ Rp. 5.194 .840

Laba Bersih $=$ Laba kotor - Pajak atau perizinan bulanan

$=$ Rp. $5.194 .840-$ Rp. 500.000

$=$ Rp. 4.694 .840

6. Break Even Point (BEP)/ Titik Impas

$$
B E P=\frac{\text { Biaya Tetap }}{\text { Harga Jual Satuan }-\frac{\text { Biaya Tidak Tetap }}{\text { Kapasitas Produksi per bulan }}}
$$


7. Benefit Cost Ratio (B/C Ratio)

$$
B / C \text { Ratio }=\frac{\text { Penjualan }}{\text { Biaya Produksi }}
$$

Berikut analisis usaha Selai Apel adalah :

\section{a. Biaya Produksi}

Biaya produksi merupakan biaya yang dikeluarkan selama usaha dijalankan, yang dibedakan atas biaya tetap dan biaya tidak tetap. Total biaya produksi tiap bulan adalah Rp. 92.305.160 dengan rincian total dari biaya tetap dan biaya tidak tetap.

- $\quad$ Biaya Tetap (Fixed Cost)

Biaya tetap adalah biaya yang tetap dikeluarkan meskipun perusahaan tidak melakukan proses produksi. Biaya tetap terdiri atas. Pada Tabel 1 dapat dilihat biaya tetap produksi Selai Apel setiap bulan sebesar Rp 6.187.785

- Biaya Tidak Tetap/Variabel (Variabel Cost)

Biaya variabel merupakan biaya yang dikeluarkan hanya jika melakukan proses produksi. Biaya variabel terdiri dari Biaya bahan baku, pembantu dan kemasan, biaya bahan bakar/energi, biaya tenaga kerja, serta biaya perawatan dan perbaikan. Pada Tabel 2 dapat dilihat biaya tidak tetap (variabel cost) produksi Selai Apel setiap bulan sebesar Rp 86.117.375

b. Kapasitas Produksi

Kapasitas produksi merupakan jumlah atau besarnya produk yang dapat dihasilkan oleh perusahaan selama kurun waktu tertentu. Kapasitas produksi Selai Apel setiap bulan adalah $\mathbf{2 . 5 0 0}$ botol selai/bulan dimana satu botol selai berisi $\mathbf{5 0 0}$ gr SelaiApel.

\section{c. Harga Pokok Produksi}

Harga pokok produksi merupakan harga minimal yang harus diberikan pada produk untuk menghindari kerugian. Harga pokok berasal dari biaya produksi (biaya tetap dan biaya variabel) dibagi dengan jumlah produk yang dihasilkan (kapasitas produksi). Harga pokok penjualan Selai Apel adalah Rp 36.922 /botol selai

\section{d. Harga Jual}

Harga jual adalah harga yang diberikan pada produk setelah ditambah keuntungan sesuai yang diinginkan oleh perusahaan berdasarkan harga pokok, sehingga untuk memperoleh keuntungan maka harga jual harus lebih tinggi dari harga pokok. Harga jual Selai Apel adalah Rp 39.000,00 /botol selai.

\section{e. Laba (Keuntungan)}

Laba (keuntungan) merupakan selisih antara pendapatan dan pengeluaran atau selisih antara harga jual dengan harga pokok. Laba perusahaan meliputi laba kotor dan laba bersih. 


\section{7 | MALLOMO: Journal of Community Service}

a. Laba Kotor

Laba kotor merupakan laba yang diperoleh dari selisih hasil penjualan dengan biaya produksi sebelum dikurangi biaya perizinan usaha. Laba kotor produksi Selai Apel sebesar Rp5.194.840,- dari 2.500 botol selai.

b. Laba Bersih

Laba bersih merupakan laba yang diperoleh dari selisih laba kotor dengan pajak kepemilikan usaha. Laba bersih produksi Selai Apel setiap bulannya adalah Rp 4.694.840,- dari 2.500 botol selai.

\section{f. BEP (Break Even Point)}

Break Even Point merupakan titik keseimbangan dimana pada titik tersebut pendapatan sama dengan biaya yang dikeluarkan, artinya titik impas dimana perusahaan tidak mengalami kerugian dan tidak mendapatkan keuntungan. Produksi Selai Apel mencapai titik impas pada tingkat produksi 1.359 botol selai dari kapasitas produksi selai setiap bulannya. Jadi selisih antara kapasitas produksi dan titik impas merupakan keuntungan yang diperoleh perusahaan. Oleh karena itu produksi Selai Apel ini masih tetap dapat berjalan.

\section{g. Pay Out Time (POT)}

Pay Out Time (РОT) merupakan waktu yang dibutuhkan oleh perusahaan untuk mendapatkan pengembalian modal dan mendapatkan keuntungan bersih. Produksi Selai Apel akan kembali modal dalam jangka waktu 18 bulan.

\section{h. B/C (Benefit Cost Ratio)}

Benefit Cost Ratio merupakan perbandingan antara pendapatan yang diperoleh dengan biaya produksi yang dikeluarkan. Jika nilai B/C lebih kecil dari 1, maka proses produksi tidak layak untuk dilakukan karena perusahaan mengalami kerugian. Sebaliknya jika B/C lebih dari 1, maka proses produksi (usaha) tetap dapat dijalankan karena perusahaan mendapatkan keuntungan. Jika $\mathrm{B} / \mathrm{C}$ sama dengan 1 maka perusahaan mengalami impas (tidak untung dan tidak rugi), artinya perlu mempertimbangkan beberapa faktor untuk tetap menjalankan usaha. $\mathrm{B} / \mathrm{C}$ ratio dari analisis usaha Selai Apel ini adalah 1,05 sehingga dapat dijadikan pertimbangan bahwa usaha ini layak untuk dijalankan. 
Analisa Kelayakan Usaha Pembuatan ... (Nurul Qisti) | 28

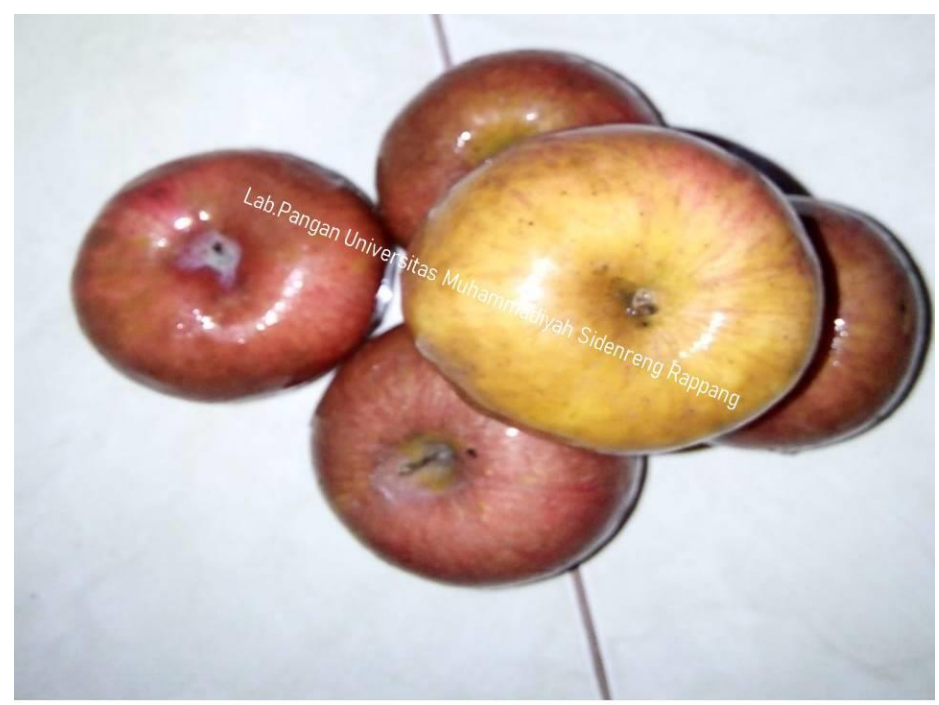

Gambar 1. Apel afkir dari toko UMS Rappang Store

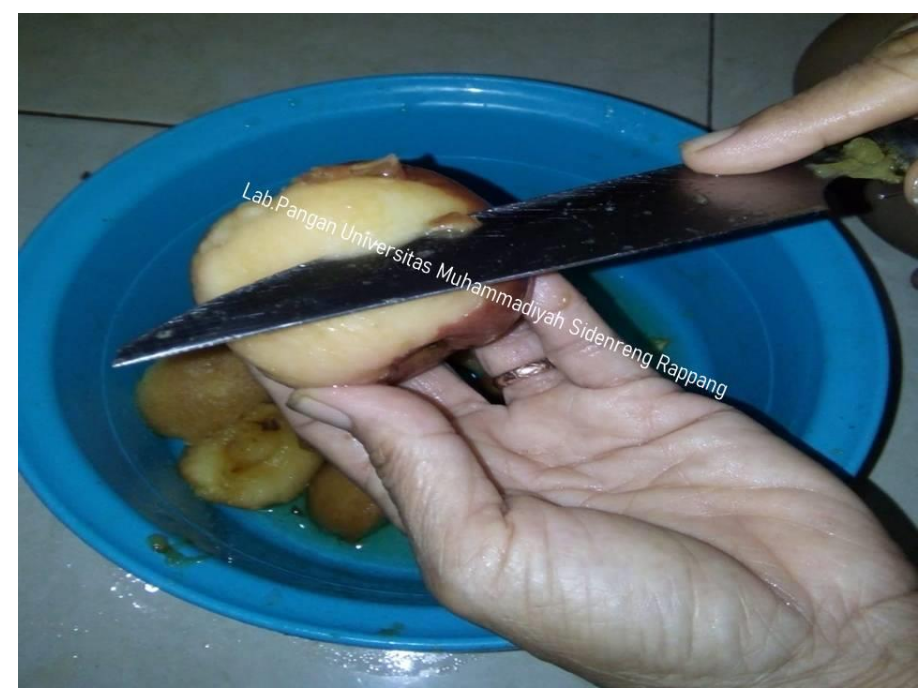

Gambar 2. Proses pengelupasan kulit dan pemotongan apel

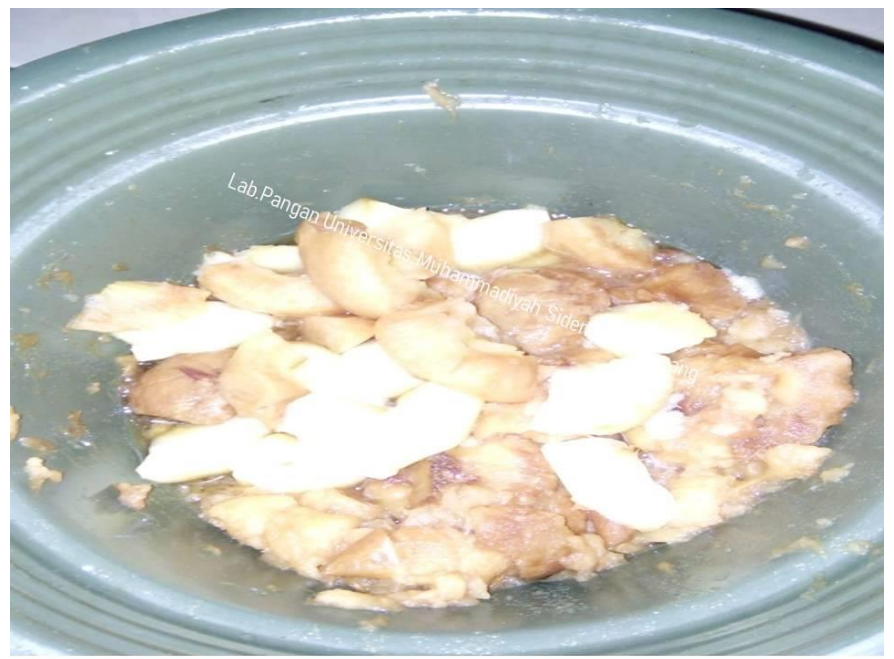

Gambar 3. Apel setelah dipotong-potong 
29 | MALLOMO: Journal of Community Service

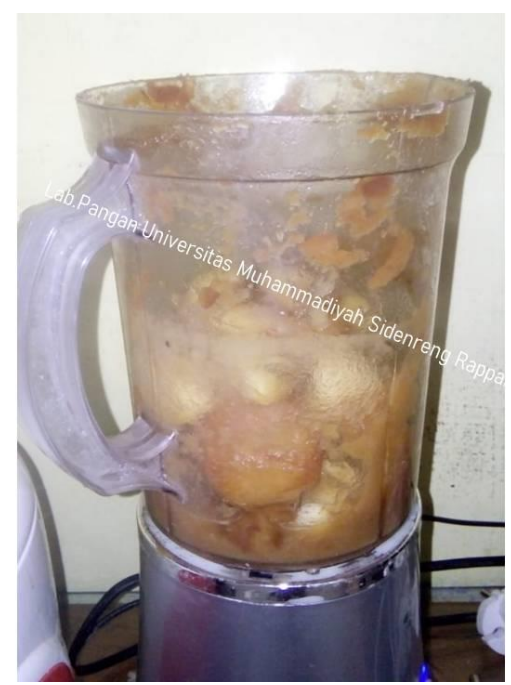

Gambar 4. Proses penghalusan apel dengan menggunakan blender listrik

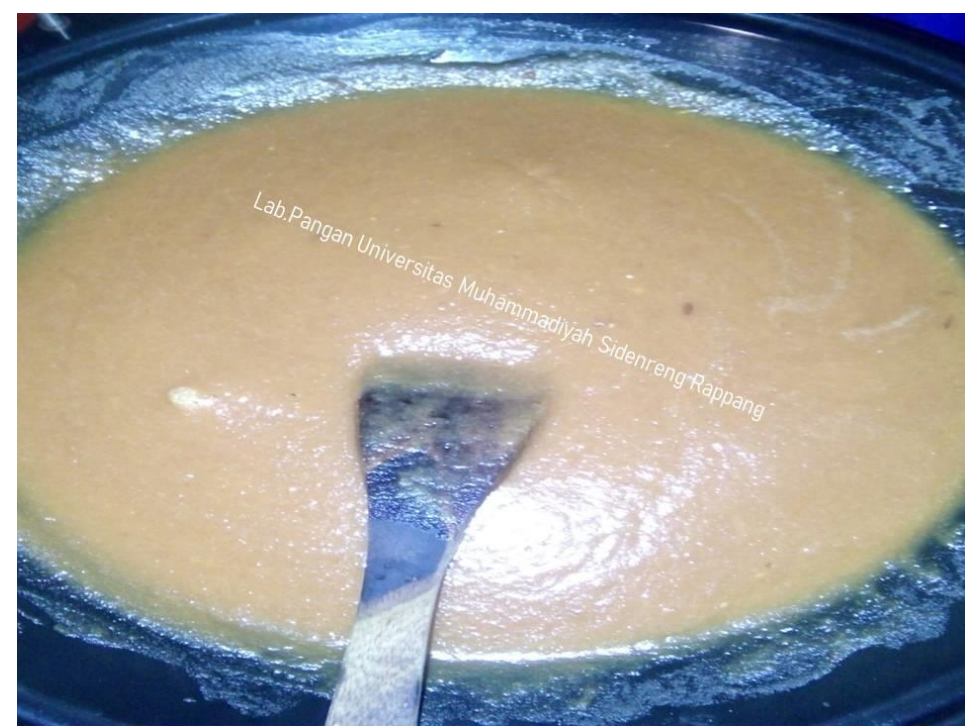

Gambar 5. Selai sesaat setelah dimasak

\section{Simpulan Dan Saran}

Kesimpulan dari kegiatan ini adalah pembuatan selai yang dilakukan menjadi alteratif usaha yang tepat, dilihat dari perhitungan analisis kelayakan usaha yang dilakukan diperoleh hasil bahwa usaha pembuatan selai layak dilakukan.

\section{Daftar Rujukan}

Susanto, T dan B. Saneto. 1994. Telmologi Pengolahan Hasil Pertanian. Surabaya: Bina Ilmu.

Sulastri L. 2016. Studi Kelayakan Bisnis Untuk Wirausaha. Bandung: LGM - LaGood's Publishing.

Nanda, Y. T. (2016). KAJIAN ALTERNATIF PEWARNA ALAMI BUNGA MAWAR MERAH (Rosa Hybrida L.) DAN BUNGA KANA MERAH (Canna Indica) DENGAN PERBEDAAN KONSENTRASI SUKROSA PADA PERMEN JELLY APEL (Doctoral dissertation, University of Muhammadiyah 
Analisa Kelayakan Usaha Pembuatan ... (Nurul Qisti) | 30

Widyaningsih, M. (2017). Identifikasi Kematangan Buah Apel Dengan Gray Level Co-Occurrence Matrix (GLCM). Jurnal SAINTEKOM, 6(1), 71-88. doi:10.33020/saintekom.v6i1.7 